\title{
WSCHODNIEGO KOŚCIOŁA STAROŻYTNEGO DOTYCZĄCE MAŁŻEŃSTWA I RODZINY
}

\author{
A. KANONY APOSTOLSKIE
}

Kanon 5:

Biskup, prezbiter lub diakon nie śmie wypędzlé swojej zony pod pozorem pobozności. Jezeli ją wypędzi, ntech bedzle wyklęty; Jeżeli zaś by się oplerał, niech będzie deponowany ${ }^{1}$.

Kanon 17:

Jeźeli ktoś po przyjęciu chrztu świętego był drukrotnie zonaty lub tez utrzymywał nałoźnice, to nie może być biskupem, prezbiterem lub diakonem, ani teź nie moze rigurować w spisie osób duchownych ${ }^{2}$.

Kanon 18:

Jeżel1 ktoś pojął za małzonkę wowę, porzuconą, jawnogrzeszntcę, niewolniç lub aktorkę ze sceny, to nie moze by ć biskupen, prezbiterem lub diakonem, ant tez nie moze figurować w splste osób duchownych ${ }^{3}$.

Kanon 19:

Kto mial za żonę dwie rodzone siostry lub bratanice, ten nie moze byé duchownym ${ }^{4}$.

$x$ Przekladu dokonano $z$ tekstu krytycznego opracowanego przez P.P.Joannou, Discipline générale antiquae, lloma 1962 - 1963, $t$.I pars 1: Les canons de Conciles Decuménlques/II $-\mathrm{IX}^{\mathrm{e}} \mathrm{s.} /$; pars 2 : Les eanons de Synodes Particuliers /IVe-IX s./; t. II: Les canons des Peres Grecs. Dla ałatwienta cytowanta poszczegóinych kanonón podajemy oddzielną lokalizacje kaźdego $z$ nich wydaniu krytycznym. Weryfikacji tłumaczenia i opracowanta lokalizacji dokonat ks.

1 Joannou 1 .

1 Joannou $1,2,10$.

2 Joannou $I, 2,16$.

3 Tamze.

4 Joannou I, 2,17. 
Kanon 26:

Spośród bezzennych, którzy wstąpili do stanu duchownego pozwalamy na małzenistwo, jeśl1 zechcą, tylko lektorom 1 kantorom ${ }^{5}$.

\section{Kanon 48:}

Jeżel1 jakiś la1k wypędzi wasną zonę 1 pojmie inną kobietę wolną lub porzucona przez kogos innego, to niech będzie wyklety ${ }^{6}$.

\section{Kanon 51:}

Jeżeli Jakí́ biskup, prezbiter, diakon lub chowna powstrzymuje się od małzenstwa, miessa 1 wina, nie ze względu na umartwiente, ale z pogardy, zapominając o tym, ze rszystko stworzone "jest bardzo dobre" 1 ze "Bóg uczyniz człowieka męzczyzną 1 kobietą" 1 w ten sposób bluźniąc rzuca potwarz na stworzenie, to albo niech sie poprawi, albo niech zostanie deponowany 1 wyłazczony z Kościoła. To samo dotyczy także laika ${ }^{7}$.

\section{B. SOBORY POWSZECHNE}

\section{Sobór Chalcedońsk1/451/}

\section{Kanon 14:}

Pontewaz $w$ niektórych prowincjach pozwala sie lektorom 1 kantorom zawierac zwizzki małzeńskie, święty synod postanowił, ze żadnemu z nich nie godzi się brać żony innowierczej. C1 natomiast, którzy juz zrodzili w takich zwiazkach potomstwo 1 postarali się juz ochrzcić swoje dzieci u heretyków, to winni je oddać wspólnocie Kościoła Katolickiego. Dzieci natomiast jeszcze nie ochrzczone, nie mogá juź otrzymać chrztu z råk heretyków, ani też łączyć się wǫzłem małźeńskim z he-

5 Joannou I, 2,19.

6 Joannou $I, 2,32$.

7 Joannou $I, 2,35-36$. 
retykiem, źydom lub poganinem, chyba źe osoba wiąząca się z prawowiernym zobowiazuje się przyjąc prawowierną wiarę: Jeżeli zaś ktoś odwaźy się przekroczý́ niniejsze postanowienie świętego synodu, to niech będzie poddany karze kanonicznej $j^{8}$.

Kanon 15:

N1e nalezy wyświęcać kobiety na diakonisę przed ukończeniem czterdziestego roku zycia 1 przed jej dokładnym sprawdzeniem. Jeźeli zaś po święceniach $i$ sprawowaniu przez pewien czas swoich Punkcji wyjdzie za mąz, wzgardziwszy łaską Bozą, to naieży ją ekskomunikowac razem z tym, z którym się zmiazzała9.

Kanon 16:

Dziewicy, która poświęciła się Panu Bogu, jak równiez zakonnikowi, nie wolno wstępować $\checkmark$ zwiazki małzeńskie. Jeżell zaś znaleźli by się tacy, którzy by to czynili, to niech będą wyklęci. Postanawiamy jednak, aby biskup miejscowy miał pełnie władzy okazywać $1 \mathrm{~m}$ miłosierdzie ${ }^{10}$.

Kanon 27:

Swięty synod postanowił, żeby tych, którzy porywajaz kobiety w celu lch poślubienta oraz tych, którzy pomagaja lub sprzedają porywaczom, jeśli są duchownymi, pozbawić własciwej im godności, a jeśl1 są zakonnikaml lub laikami - ekskomunikomac ${ }^{11}$.

2. Synod /sobór/Trullański /691-692/12

Kanon 3:

Poniewaz nasz pobożny 1 umiłowany przez Chrystusa cesarz - swym przemówientu do świętego soboru/synodu/ powszechnego

8 Joannou I, 1,80-81.

9 Joannou $I, 1,81-82$.

10 Joannou $I, 1,82$.

11 Joannou $I, 1,90$.

12 Synod ten zwołany przez cesarza Justyniana II w $691 \mathrm{r}$. uwazany 
wymagał, aby osoby należące do stanu duchownego i udzielajace 1m boźych darów pozostamały czystymi 1 nienagannymi ministrami godnymi duchowej ofiary wielkiego Boga, który sam jest Opiara 1 Arcykapłanem oraz oczyściły się ze zmazy, która przylgnęła do nich na skutek niedozwolonych zwiazk $\delta$ wałzeńskich, a ponadto, pontewaz przedstawiciele wielce świętego Kośc1oła rzymskiego proponują sumiennie przestrzegać kanonu, a poddani tronu tego strzezonego przez Boga cesarskiego miasta Konstantynopola/ przestrzegać zasady humanitaryzmu 1 wyrozumiałości, to my połączywszy po ojcorsku 1 w sposób miły Bogu w jedno te obydwie tendencje, tak jednak, aby z dobroci alo uczynic słabości, a z surowośc1 okrucieństwa, zwłaszcza, híedy mamy do czynienta z nieśriadomym popełnieniem grzechu przez niemała liczbę osób, zgodnie postanawiamy, aby ci, ktorzy zawarl1 powtórny zwizzek małzeński 1 do 15 dnia ubiegłego miesiąca stycznia, minionego 4 indyktu 6199 roku pozostawal1 warzmie grzechu 1 nie chciel1 się od niego odzegnab, zostall poddani kanonicznej depozycj1.

Ci natomiast, którzy ściągnęli na siebie taką hańbę powtórnego małzeństwa, ale przed naszym zebraniem sie pozna11 to co jest pozyteczne, odsunęli od siebie zło 1 całkowicie zerwali z tym nlewłaściwym i bezprawnym współżciem, a takze ci, których zony z drugiego małzeństwa juz zmarły, jak równiez c1, którzy pragnąc nawrócenia znów uczą się wstrzemięźl1roscl zapomntawszy szybko o swych poprzedntch nieprawościach czy sa to kapłani, czy diakoni, czy subdiakoni - to względem nich postanowiono, aby sie powstrzymali od wszelkiej kapłańskiej 1 liturgicznej działalności, poddawszy się pokucie na pewien określony czas, korzystając jednak z zaszczytu siedzenia 1 stania/wśród duchownych/, zadawalając się tym plerwszeństwem 1 błagając z płaczem Pana, aby darował im grzech niewedzy. Byłoby rzeczą niewłaściwą, gdyby błogosławieństwa innemu udzielał ktoś, kto sam winten leczyc własne rany.

jest przez Kościóz Wschodni za VI Sobór Ekumentczny lub II Sobór "In Trullo", "Kościele Zachodnim zaś nazywany jest on przewaznte synodem. 
Tych zaś, którzy posiadall jedną zonę, ale poślubiona przez nich niewiasta była mową, jak równiez tych, którzy po święcentach zawarli jeden związek małzeńsk1 - czy sa to prezbiterzy, czy diakoni, czy subdiakont - nalezy po odsunięciu na pewien krótki czas od swiętych czynnośc1 liturglcznych 1 po pokucie znowu przywracac na dawne stopnie, nigdy Jednak na inny wyższy stopleń, oczywíscie wyłącznie po uprzednim rozwiazzaniu ich nieprawego związku.

Postanowienie to dotyczy tych, których wina została mykazana, Jak to mypowiedztano juz wyzej, do dnia 15 stycznta 4 Indyktu 1 odnosi się tylko do osób duchownych. Odtąd zaś ustanawlamy 1 odnawiamy kanon następujący: "Kto po przyjeciu chrztu byz dwukrotnie zonaty lub utrzymywał nałoznice, ten nie moze być ani biskupem, ani prezbiterem, an1 diakonem, ani teź nie moze figurować $\$$ spisie osób duchownych" /Ap.17/. Podobnie: "Kto pojął za małzonke wowę, rozwiedz1oną, jawnogrzesznice, niewolniç, lub aktorke ze sceny, ten nie moze być ani biskupem, ani prezbiterem, ant diakonem, ani też nie moze elgurowác w spisie osób duchownych"/Ap.18/13.

Kanon 4:

Jezeli jakiś biskup, prezbiter, diakon, subdiakon, lektor, kantor lub ostiariusz obcował z niewiastą poświęconą Bogu, to niech będzie deponowany, ponteważ zhańbil oblublentce Chrystusową. Jezeli to był laik niech będzie wyłączony ze społeczności kościelnej ${ }^{14}$.

Kanon 6:

Pontewaz w Kanonach Apostolskich powiedzlano, ze "spośród wstęujących do stanu duchownego wtanie bezzennym związek małzeński mogaz zawierá jedynte lektorzy i kantorzy" /Ap.26/, to 1 my tego przestrzegając postanawiamy, ze odtąd nigdy ani subdiakon, ant diakon, ant prezbiter nie ma prawa zawierać

13 Joannou $I, 1,125-130$.

14 Joannou $I, 1,130$. 
związku małzeńskiego po przyjęciu św1ęceń. Jezel1 zaś odwazj się to uczynić, to niech będzie deponowany. Jeżeli zaś ktoś z osób wstępujących do stanu duchownego zechce poślubić kobietę zgodnie z prawem małźeńskim, nlech to uczyni przed świeceniami subdiakonatu, diakonatu lub prezbiteriatu ${ }^{15}$.

Kanon 12:

Dowiedzieliśmy się 1 tego, że w Afryce, w Libil 1 innych miejscach niektórzy spośród tamtejszych miłych Bogu przełoźonych/biskupów/ nie zaprzestali mieszkać razem ze swymi zonami nawet po otrzymaniu święceń 1 dają przez to innym ludzlom powód do upadku 1 zgorszenia, to mając na uwadze dobro powierzonej nam owczarni, uznaliśmy za rzecz właściwą, aby odtąd nic podobnego nie miało miejsca. Mówimy zaś o tym nie dlatego, żeby odrzucić lub też zmienić kanoniczne zasady apostolskie, lecz aby wzmóc troskę o zbawiente ludzi 1 lch postęp cnocie, a także $w$ tym celu, zeby nie dopuścić do zadnych zarzutów przeciwko dyscyplinie kościelnej. Apostoz bowiem powiedział: "wszystko czyńcie na chwàłę Bozą. Nie bqdźcie zgorszeniem ani dla Zydów, ani dla Greków, ani dla Kosc1oła Bozego, podobnie jak ja staram się przypodobać wszystkim, nie szukając zadnej korzyści, lecz dobra wielu, aby zostall zbawient. Bądźcie naśladowcami molmi, jak 1 ja jestem naśladowcą Chrystusa"/1 Kor 10,31-11,1/, zaś jeżel1 ktoś zostanie wykryty, ze to czyni, to niech będzie deponowany ${ }^{16}$.

Kanon 13:

Pontewaz dowiedzieliśmy się, ze Kościele rzymskim podano jako zasadę, która głosi, ze ci, którzy maja otrzymaé święcenia diakonatu lub prezbiteratu, aby tego byli godni, składają ob1etn1ce poniechania wsp6łzycia ze swymi małżonkam1, to my, idazc za dawnym kanonem apostolskiej doskonałosci i dyscypliny chcemy, aby małźeństwa ludz1 poświęconych Bogu zawarte zgodnie $z$ prawem nadal pozostawały nienaruszone 1 aby 
c1 nie zrywali swej więzi z zonami oraz nie pozbawiali sie wzajemnego obcowania w odpowiednim czasie. Jeżeli ktoś jest godnym święceń subdiakonatu, diakonatu lub prezbiteratu, to Jego zamieszkiwanie z prawowita zoną nie moze stanowić przeszkody na drodze podniesienia go do tej godności i podcz święceń nie należy żądáć od niego zobowiazania, ze będzie powstrzymywał się od prawowitego obcowania ze swojaz zona. W przeciwnym razie ponizalibysmy ustanowione przez Boga 1 pobłogosławione Jego obecnościa małzeństwo, ponieważ głos Ewangel11 woła donośnie: "Co Bdg złączył, człowiek niech nie rozłacza" Mt 19,6/, a Apostoł poucza: "Uczciwe niech bodzie małzeństwo 1 łoze nieskalane" /Hbr, 13,4/, oraz mów1: "Jesteś zwiazzany z zoną? Nie usiłuj odłączyé się od niej"/1 Kor 7 , $27 /$.

Wlemy, że ojcowie zgromadzeni wartaginie, troszcząc się o czystość zycia sług ołtarza, postanowill, "źeby subdiakont dotykający świętych mysteriów, jak równieź diakoni 1 prezbiterzy dla tych samych racji powstrzymywall się od swych zon $w$ ustalonym czasie, abyśmy 1 my podobnie przestrzegall tego, co zostało przekazane przez Apostołó 1 co było zachowywane juź od najdawniejszych czasów, znając właśoiwy czas dla każej rzeczy, a zwłaszcza dla postu 1 modlitwy. Trzeba bowiem, żeby ci, którzy zbliżaja się do ołtarza, podczas sprawowania mszy świętych byl1 wstrzemięźliwi we wszystkim, aby mogli otrzymać od Boga to, o co pokornie proszą". Jeżel1 więc ktoś, postępując wbrew kanonom ápostolskim, odważyłby się pozbawić jakiegoś duchownego, to jest prezbitera, diakona lub subdiakona, wiezi 1 obcowanta z prawowita żoną, to niech będzie deponowany. Podobnie, jeżeli jakiś prezbiter lub diakon wypędzi swoja zonę pod pozorem pobożnośc1, to niech będzie odsunięty od Punkej1 liturgicznych, a gdyby się lpierał, to niech będzie deponowany ${ }^{17}$.

Kanon 26:

Prezbiter, który przez niewiedzę uwikłał się w nieprawe

17 Joannou $\mathrm{I}, 1,140-143$. 
mazzeństwo, zachowuje wprawazie swoja pozycję, zgodnie ze świetym kanonem przez nas ustanowionym, ale niech się powstrzyma od pozostałych funkcj1, gdyz wystarcza mu juz przebaczente. Byłoby rzeczą nierozumna, zeby ten, kto sam winten leczyć własne rany, innym udzielał błogosławieństwa. Błogosławieństwo jest bowiem udzielaniem uświęcenta, a kto go sam uie posiada na skutek grzechu z niewiedzy, to jak go udzieli Innemu? Niech więc nie udziela błogosławieństwa ani publicznie ant prywatnie, ani niech nie rozdziela innym Ciała Pangkiego, ant tez niech nie pełni innych funkcji, lecz zadawalając sie miejscem należnym prezbiterowi, niech ze łzami błaga Pana, aby darował mu grzech popełniony z niewiedzy. Jest oczywiste, ze taki nieprawy zwiazek małzeński zostanie rozwlązany, a mąz n1e będz1e współzył z tą kobietą, która stała sie powodem zawieszenia go runkojach kapłanskich ${ }^{18}$.

Kanon 30:

Pragnąc czynic wszystko dla zbudowanla Kościoła, postanowiliśmy równiez zatroszczyé sie o duchownych obsługujących kościoły krajach barbarzyńskich. Jeżel ci ưaźają, ze moga przekraczać kanon apostolski zabraniający "wypędzania swojej zony pod pozorem pobozności" oraz czynté miecej niz postanowiono 1 dlatego za obopólna zgoda porstrzymują się ze swymi współmałzonkamt od wajemnych relacj1, to my zarządzamy, zeby pod zadnym pozorem równieź z nimi nie zamieszkiwali 1 dostarczyli nam tym sposobem przekonywujacego dowodu na dotrzymante swej obletnicy. Zezwolilismy im zaś na to myłącznle ze względu na $1 \mathrm{ch}$ małodusznośc oraz obce 1 ntestaze obycraje ${ }^{19}$.

Kanon 47:

Niech zadna niewiasta nie nocuje klasztorze męskim, ani mezczyzna zeńatim. Trzeba bowiem chronic wiernych przed skandalem 1 zgorszentem, aby układall swoje tycie "według tego co jest godne 1 miłe Panu"/1 Kor 7,35/. Ktokolwiek

18 Joannou $I, 1,156-157$.

19 Joannou $I, 1,160-161$. 
zaś by to czynit, duchowny czy świeck1, niech będzie wy$k 1$ eqty 20

Kanon 48:

Zona tego, który został wyniesiony do godności biskupiej, niech po rozstaniu się ze swolm mężem za obopólną zgodz 1 po przyjęciu przez niego ś⿴囗十 ęcen biskuplch, vstąpi do klasztoru znajdującego sie daleko od miejsca zamieszkania tego biskupa 1 niech korzysta z utrzyman1a biskupa. Jeżeli zaś wydawałaby sie tego godna, niech zostanie podniesiona do godności diakonisty 21 .

Kanon 53:

Poniewaź powinowactwo duchowe jest waźniejsze od cielesnego, a dowiedzieliśmy się, ze w niektórych miejscuwościach są tacy, którzy najpierw trzymaja dziecko do świętego 1 zbawczego chrztu, a potem zawierają związki małzeńskie z $1 \mathrm{ch}$ ordowiaIymi matkami, to postanawiamy, aby odtąd nic takiego juz nie czyniono. Jeżell zaś okaze się, ze nawet po ogłoszeniu niniejszego kanonu, niektórzy nadal tak postepuja, to najpier nlech odstąpią od tego nieprawego małzeństwa, a następnie niech będą obłożeni karą przepisaną za cudzołóstmo 22 .

Kanon 54:

Pismo Swięte poucza myraźnie: "Nie zblizaj się do c1ała swego krewnego, aby odsłonic. jego nagoścn / Kpz 18,6/. Natchniony przez Boga Bazýli wymienił w swych kanonach Jedy nie niektóre z zakazanych zwiazków małżeáskfch ${ }^{23}$, ponijajace milczeniem większość Innych, a uczynił to w obu wypadkach

20 Joannou $I, 1,185-186$.

21 Joannou $I, 1,186$.

22 Joannou $I, 1,189-190$.

23 Por. Epistola 199 /Ad Amphiloch1um/, 23; Epistola 217, 58-60, 67-68, Joannou II, 125,145-146, 148-149, tłum. T.Krzyzaniak /Sw.Bazy 11, L1sty, Warszawa 1972/s.207,238-240. 
z pożytklem dla nas. Unikając bowiem wielu gorszących nazw, aby nie bezcześcić takimi siowami mowy, określiz on nteczyatoś tylko ogólnymi nazwami, za pomocą których ukazał nam ogólnym zaryste wypadki nieprawych zwiazzków małzeńskich. Ponlewaź jednak ze mględu na tego rodzaju przemilczenia 1 niejasne sformuzomania zakazu niepramych małzeństw natura reszaca sarą sleble, uznaliśmy za konieczne jaśniej te sprawy przedstawic 1 odtą postanawiamy: Jezell ktos zamrze zwizes maźerísk z córka swego brata, albo ojciec i syn z matka 1 córka lub ojciec 1 syn z dwoma siostram1, albo matka 1 córka $z$ dwome braćmi lub tez dwaj bracia $z$ dwoma siostra壁, to niech beda poddani kanonicznej karze siedmiu lat [pokuty]. oczywícle po rozwiazaniu lch nieprawego malzeństwa ${ }^{24}$.

Kanon 72:

Nio godzl sie, aby męczyzna ortodoksyjny zenit się z kobieta hereiyczlsa, ani toz kobieta ortodoksyjna wiazała się z heretyklem. Jeżell jednak ujawnl sie, ze coś takiego przez sogó zostaio dokonane, to małzeństwo nalezy uwazać za niewazne, nieprawy kontrakt malzeńskl rozwiozac. Nie trzeba bowlem mieszać tego, co nle moze być zmieszane, ant teź łaczyć omcy z wilkiem, czy losu Chrystusa z losen grzeszników. Jezell zaś ktoś naruszy wydane przez nas postanowlenie, to niech bedzle myklęty. Jezeli natomiast ci, którzy jeszcze sa nlewierzacy $i$ nle zostali waczeni do owczarni ortodoksyjnej, zawarl1 medzy soba prawny zwiazzek małzeński, a potem jedno z nich obrawszy to, co jest dobre, doszło do światła prawdy, a drugie pozostało więzach błędu, nie chcąc skierować wzroku na boskie promienle, nlewierzaca zaś zona życzy soble meszkac razem $z$ wierzacym małżonkiem lub tez niewlerzacy mą z wierzaca małtonka, to niech się nie rozłaczaja, w mýl /słón/ Pawa Apostoła: "Uświęca się bowiem mąz niewierzący dzięl swej zonle, podobnte jak ntewierząca zona uśrięca ste przez męza" $/ 1$ Kor $7,14 / 25$. 
Kanon 87:

"Jeżeli żona opuści swego męża i wyjdzie za innego, to jest cudzołożnicł", według/słów/ świętego i boskiego Bazylego"26, który to bardzo trafnie zebrał z proroctwa Proroka Jereriasza: "Jeżeli żona wyjdzie za inney̧o męża i nie powróci do swego męża, to przez skalanie będzie skalana" /Jer 3,1/ oraz "Kto trzyma cudzołożniç, głupi jest $i$ bezbożny"/Prz 18,22/. Jeżeli zostanie dowiedzione, że żona opuściła swego męża bez przyczyny, to on jest godzien przychylności, ona zaś kary. Ta przychylność będzie się wyrażała w tya, że pozostanie on we wspólnocie Kościoła. Ten, jednak kto opuści prawnie poślubionzżonz i weźmie inna, to według słów Pana /Lk 16,18/ winien być oskicżony o cudzołóstwo. Kanony ojców naszych postanowiły, żeby tacy pozostawali przez rok wśród płaczłcych, przez dwa lata wśród słuchajzcỷch, przez trzy lata wśród klęczących, a w siódmyn roku stali $z$ wiernymi $i$ w ten sposób uznani byli za godnych ofiary, jeśli ze łzami będa pokutować 27 .

Kanon 92:

Swięty synod postanowì, żeby tych, którzy porywajzkobiety pod pretekster małzeństwa oraz tych którzy z porywaczami współdziałaja lub im pomagaja, pozbawlać właściwej im godności, jeśli sa duchowny wi, lub wyklinać, jeśli sa laikami 28.

Kanon 93:

Kobieta zamieszkujłca $z$ innym mężcyznz połczas nieobecności swego meża, o któryia nie ma wiadomości ani dowodów jego śmierci, dopuszcza się cudzołóstwa. Podobnej ocenie podlegajz wychodz̧̨ce ponownie za raż zarórno żony żołnierzy, o których wieść zaginęła, jak i żony nie oczekuj kce powrotu swych męzọ́, którzy udali sia w daleḱ yodróż. Można tutaj jednak okazywać pewnz pobłażliwość ze wzgl̨̨du na większe prawdopodobieństwo ich śmierci. Jejeli kobieta z niewiedzy poślubiła męźczyznę porzuconego czasowo przez żonz, ale póżniej, po powrocie jegro prawnej małżonki została przez niego opuszczona, to wprawdzie zcudzołożyła, ale z niewiedzy $i$ nie traci z tecro powolu prawa do małżeństwa, choé będzie lepiej, gdy jozostanie sama. Jeżli natomiast po pewny czasie powróci zołnierz, którego żona na sirutei jego dłuriej nieobecności

26 Basilius, Canones 9,35,37,77, Joannou II, 108-109,132,133, 153, Krzyżaniak, S. $191,210,242$.

27 Joannou I, 1,222-224.

28 Joannou I, 1,227-228. 
poślubiła innego mężzyznę, to niech znowu weźmie, Jeśli chce mlasną zon̨, a trzeba przy tym przebaczýc zarómno jej, z powodu niewiedzy, jak i męzczyźnte, który ją poślubił - drugim małzeństwie 29 .

Kanon 98:

Kto zawiera małzeństwo z kobieta zaręczona z innym męzczyzną, jeszcze za życia narzeczonego, podlega oskarzeniu o cudzoł6stwo 30 .

\section{KANONY SYNODOW LOKALNYCH}

1. Synod w Ancyrze /314/

Kanon 10:

Jezeli kandydaci do diakonatu oświadczyli publicznie podczas swych święceń, że muszą zawrzeć związek małżeński 1 nie moga pozostawać jako bezżenni, to po zawarciu małzeństwa niech pełnia nadal swe lunkcje, ponteważ otrzymali na to pozwolenie od biskupa. Jeźeli natomiast niektórzy przemilczeli to zastrzezenie $i$ podczas śrieceń zobowiazali się do pozostania w stanie bezżennym, a potem wstąpili w związki małzeńskie, to musza zaprzestać swych funkcji diakońskich ${ }^{31}$.

Kanon 11:

Dziewczęta zareczone, a następnie przez innych uprowadzone, postanowiono zwracać ich oblubleńcom, nawet gdyby od porywaczy doznały przemocy tizycznej ${ }^{32}$.

Kanon 19:

C1, którzy przyrzekali dziewictwo 1 złamalı swe przyrzeczenie, powinni pokutować z bigamistami. Zabraniamy oczywiście

29 Joannou I, 1, 228-229.

30 Joannou $1,1,235$.

31 Joannou $I, 2,64$.

32 Joannou $I, 2,64-65$. 
mieszkać dziewicom razem z innymi /mężczyznami/ jako z brać$\mathrm{mi}^{33}$.

Kanon 20:

Jezeli czyjaś zona cudzołozyła lub też jakiś /mąz/ cudzołoży, to moga powrócić do pełnej wspólnoty/kościelnej dopiero po siedmiu latach, przechodzac kolejne stopnie pokuty ${ }^{34}$

Kanon 21:

Stare zarządzenie ekskomunikowało aź do końca życia kobiety, które trudniąc sie nierządem zabijaja swe dzieci lub dopuszczają się spędzania płodu. My natomiast postępując ragodniej zarządziliśmy, aby one odbywały dziesięcioletnią pokute według ustalonych stopni ${ }^{35}$.

Kanon 25:

Pewien mężczyzna po zaręczynach z dziewczyną najpierw zdeprawował jej siostre, która zaszła w ciąże, a następnie ozentz się z zaręczoną; zgwałcona zaś siostra powiesiła sie. Postanowiono, żeby dopuścié mspółwinnych po odbyciu dz1esięcioletniej pokuty według ustalonych stopni, do grona stojacych pokutników ${ }^{36}$.

2. Synod w Neocezarei /314/

Kanon 1:

Jeżeli prezbiter zawrze zwiazek mazzeńsk1, to niech zostanie usunięty ze stanu kapłańskiego. Jeśliby natomiast uprawiał nierząd lub dopuścił się cudzołóstma, niech całkowicie zostanie wyłączony ze wspólnoty kościelnej $i$ poddany pokuc1e 37 .

Kanon 2:

Jezeliby kobieta poślubiła dwóch braci, to niech będzie wy-

33 Joannou $I, 2,70$.

34 Joannou $I, 2,70$.

35 Joannou $I, Z, 71$.

36 Joannou $I, 2,73$.

37 Joannou $I, 2,75$. 
klęta aż do śmierci. Jeżeliby jednak w obliczu śmierci obiecała, że po wyzdrowieniu zerwie to małzeństwo, to z miłosierdzia niech zostanie dopuszczona do pokuty. Jeżeli zaś trwająca w takim małżéstwie żona lub maź umrze, to dla pozostałej strony pokuta będzie sprawą trudną ${ }^{38}$.

Kanon 3:

Znany jest czas odbywania pokuty nakładanej na tych, którzy się wielokrotnie źenia, lch jednak nawrócenle się 1 wiara skracaja ten okres ${ }^{39}$.

Kanon 7 :

Niech prezbiter nie uczestniczy w uczcie megelnej tego, który sie po raz drugi żeni, ponieważ wymaga on pokuty. Cóz by to byz za prezbiter, któxy by poprzez uczestnictwo wczcie pochwalaz takie małżéstwo? 40

Kanon 8:

Jeżeli żonle jakiegoś laika zostanie publicznie dowiedzione cudzołóstwo, to jej mazz nie moze być dopuszczony do źadnych Iunkcji wościele. Jeżeli cudzołożyła po święcentach męża, to ten winien ją odesłać. Jeżellby z niaz jednak nadal wspóxżył, to nie może pełnić powierzonej mu Punkcji 41 .

Kanon 9:

Jeżeli prezbiter popełnit grzech cielesny, a po otrzymaniu święceń wyznal, że zgrzeszyz przed swięceniani, to niech nie sklada ślietej ofiary, zachowujac wszystkie swoje pozostałe Punkcje ze wg leqdu na gorliwość w innych cnotach. Pozostałe bowiem grzechy sa, gladzone, jak wielu náucza, poprzez świecenia. Jezeli zaś sam nie wyzna/grzechu/ I nie mozna mu tego udowodnić, trzeba to pozostawié jego sumienlu².

38 Joannou I, 2,76.

39 Tamì。

40 Joannou $I, 2,78$.

41 Joannou I, $2,78-79$.

42 Joannou $I, 2,79$ 。 
Kanon 10:

Fówniez diakon, jeśliby popeznil taki sam grzech, winien pełnić funkcje nizszego rzęư ${ }^{43}$.

3. Synod Gangrze /ok. 343/

Kanon 1:

Jeśliby ktoś ganił małzeństwo oraz pogardzał wierna i pobożną żona obcująca ze swoim mężem, potępiając ich, ze nie moga wejść do Królestwa /Boźego/, to niech będzie wyklety ${ }^{44}$.

Kanon 9:

Jeśliby ktoś zachowywal dziewictwo lub wstrzemieziliwość, powstrzymując sie od makzeństwa $z$ pogardy dla niego, a nie ze względu na piękno i świetość dziewictwa, to niech będzie wyklety 45 .

Kanon 10:

Jeśliby ktoś spośród zachowujących dziewictwo ze względu na

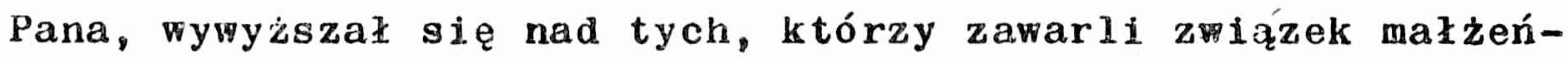
sk1, to nlech będzie wyklęty 46 .

Kanon 14:

Jeśliby jakaś żona opuściła swego męża i chciała odejść od niego z pogaray dla małzeństwa, to niech będzie wyklęta $a^{4}$.

Kanon 15:

Jeśliby ktoś opuszçał swe dzieci, nie żywił ich oraz wiarę swych możliwości nie prowadził do należytej pobożności, ale je zaniedbywał pod pretekstem ascezy, to niech będzie wyk 1 ęty $\mathbf{y}^{48}$

43 Joannou I, 2,80.

44 Joannou $I, 2,89$.

45 Joannou I, 2,93.

46 Joannou $I, 2,93$ 。

47 Joannou $I, 2,95$.

48 Joannou $I, 2,95$. 
Kanon 16:

Jeśliby jakieś dzieci opuściły swolch rodziców, zwłaszcza wierzących 1 nie oddawały naleźnej czci tym, którzy równiez bez wątpienia cenią ponad wszystko pobożność, to niech będą wyklęte 49 .

Epilog:

/.../ oddajemy cześć małżeństwu pełnemu skromności /.../. Pragniemy, aby w Kościele zostało zachowane to wszystko, co zostało przekazane z Pisma Swiętego 1 Tradycji Apostolskie ${ }^{50}$.

4. Synod w Laodycei/koniec IV w./

Kanon 1:

Postanowiliśmy zgodnie z prawem kościelnym, aby tym, którzy zawarli zwiazzek małżeński po raz drugi, dobrowolnie 1 zgodnie z prawem, bez ukrywania swego obcowania, przywrócić z łaskawości wspólnotę [z Kościołem] po upływie krótkiego czasu, jaki spędzili na modlitwach 1 postach 51 .

Kanon 10:

Ludzie należący do Kościoła nie powinni obojętnie żenić swych dzieci z heretykami 52 .

Kanon 31:

Nie należy zawıerac zwi zzków małżeńskich z żadnymi heretykami, ani oddawać im małżeństwo swoich synów i córki, ale raczej przyjmować, jeśli przyrzekną, ze zostaną chrześcijanami ${ }^{53}$.

Kanon 52:

W okresie Wielkiego Postu nie nalezy zawierać zwiazków małżeńskich ani teź obchodzić urodzin ${ }^{54}$.

49 Joannou $1,2,96$.

50 Jaannou $I, 2,98-99$.

51 Joannou $I, 2,130$.

52 Joannou $1,2,134-135$.

53 Joannou $I, 2,143$.

54 Joannou $I, 2,151$. 
5. Synod w Kartaginie /419/

Kanon 4:

Postanowiono, aby biskup, prezbiter, diakon 1 wszyscy dotykający święości zachowywali czystość 1 powstrzymywali się od wspózźycia ze swymi żonami ${ }^{55}$.

\section{KANONY OJCÓW KOSCIOLA}

1. Dionizy Aleksandryjski / $+246 /$

Kanon 3:

Ci, którzy zawarli zwiz̨zek małżeński, sami sobie winni być wystarczajacymi sędziami.Słyszeli bowiem/słowa/ św.Pawła, który napisał, że należy się czasowo powstrzymywać za obopólnaz zgodą od współżycia, aby ćwiczyć się wodlitwie, a potem znowu wracać do siebie $/ 1$ Kor $7,5 / 56$.

2. Bazyli Wielki $/+379 / 57$

Kanon 87:

Pierwsza i najważniejszą rzeczid, w sprawach tego rodzaju jest zachowywany $u$ nas zwyczaj, który przytaczamy jako majacy moc prawa, gdyz zasady te zostały nam przekazane przez świętych męzów. Jest on następujący: jeżeli ktoś opanowany przez nieczyste pożądanie zawarłby bezprawny zwizzek kolejno z dwoma siostrami, to nie będzie on uznany za małzeństwo, ani tez tacy nie będa dopuszczani zupełnie do wspólnoty kościelnej, dopóki nie rozłączá się ze sobą. Dlatego choćby nawet nie można byīo powiedzieć czegoś innego, to wystarczy $ı$ by sam zwyczaj do ustrzeżenia przed złem. Poniewaz jednak autor listu usiłował poprzez fałszywy dowód

55 Joannou I, 2,217.

56 Joannou II, 13.

57 Kanony św.Bazylego zawarte sa w jego listacin, które przeloży 
wprowadzić w życie takic $z \Varangle 0^{58}$, to i nam należy sięgnąć do pomocy rozsłaku, chociaż u każdego w sprawach bardzo jasnych intuicja bywa mocniejsza od dowodów. Napisano bowiem, jak on mówi, w Ksį̨dze Kapłańskiej: "Nie poślubisz sobie jako zazdrosnej rywalki siostry twojej żony i nie będziesz odsłaniał jej nagości za życia tamtej"/Kpł 18,18/. Z tekstu tego wynika jasno, jego zdaniem, że wolno poślubić siostrę żony po śmierci małżonki. Na to przede wszystkim odpowiem, ze "cokolwiek mówi prawo, to mówi do tych, którzy są pod prawem" / iz 3,19/. Inaczej bowiem podlegalibyśmy obrzezaniu, prawu szabatu i zakazowi spożywania niektórych pokarmów. Czyż więc, gdy znajdziemy coś sprzyjającego naszym upodobaniom, będziemy się "poddawać pod jarzmo niewoli Prawa/Gal 5,1/, a gdy któryś z przepisów Prawa jest zbyt cięzk1, to będziemy uciekać do naszej wolnośc1 w Chrystusie? Zapytano nas: czy istnieje w Piśmie pozwolenie na wzięcie za żonę siostry zmarłej małżonki? Daliśmy odpowiedź dla nas bezpiecznaz i prawdziwą, że nie jest tak napisane, ale gdybyśmy tylko taka odpowiedziz zakończyli całą sprawe, to znaczyło by to, że zachowujemy prawo, ale nie cytujemy słów Pisma. W ten sposób nawet ten, kto chciałby wziąć siostrę żony, mógłby uczynić to jeszcze za życia małżonki, bo 1 takie fałszywe rozumowanie może być tu zastosowane. Napisano bowiem, powie on, że "nie weźmiesz zazdrosnej rywalki", a więc Zakon pozwala poślubić taką, która nie jest zazdrosna. Może więc obrońca pożądliwości po-

na jezzyk polski W.Krzyżaniak/Sw.Bazyli Wielki, Listy, Warszawa 1972\%. Spośród kanonów dotyczących małzeństwa przytaczamy w tym miejscu tylko jeden $/ 87 /$, inne zaś zostały juź przełożone przez wspomnianego tłumacza $i$ do jego przekładu odsyłamy zainteresowanych Czytelników: kan.1, Joannou II, 93-99/Ep. 55, Krzyzàniak 187-193/; kan. $25,26,27,30,31,35,36,37,38,39,40,41,42,46,48,49$, 50, Joannou II, 126-128, 130-139/Ep. 199 ad Amphilochium, Krzyżaniak 207-213\%; kan. $53,57,58,69,75,76,77,78,79,80$, Joannou II, 143-154 /Ep. 217 ad Amphilochium, Krzyżaniak 237-242/.

58 Bazyli udpowiada tu na list nieznanego nam bliżej autora, występującego pod nazwiskiem Diodora, który wbrew rygorystycznej nauce Biskupa Cezarei zezwalał na małzeństwo z siostra zmarłej żony. 
wiedzieć, że siostry wolne saz od ducha zazdrości. Jeżeli więc nie ma przyczyny zabraniajłacj współżyć z obiena /siostrami/, to cóż przeszkadza wziąć siostrę? Powiemy, że tego nie napisano, a le też i nie określono. Natomiast wyprowadzony wniosek pozwala uczynić jedno 1 drugie. Należałoby cofnazć się nieco wstecz, do poprzedzajacych wypowiedzi Prawa i nimi właśnie uwolnić się od trudności. Należy też zaznaczyć, że prawodawca nie obejmuje wszystkich rodzajów grzechów, a szczególnie odrzuca grzechy. Egipcjan, skąd wyszedł Izrael i Kanaanejczyków, gdzie się osiedlił. Czytamy bowiem: "Nie czýncie tak, jak się czyni w ziemi egipskiej, w której mieszkaliście. Nie czyńcie też tak, jak się czyni w ziemi kanaanejskiej, do której was prowadzę. Nie postępujcie według ich obyczajów" /Kpł 18,3/. Prawdopodobnie ten rodzaj grzechu n1e był wtedy dopuszczalny w życiu pogan, w związku z czym prawodawca nie miał potrzeby przed nim przestrzegać, a wystarczającym dla odrzucenia jego zła było pouczenie. Dlaczego jednak zakazawszy większego/grzechu/, przemilczał mniejszy? Dlatego, ze dla wielu zwolenników cielesnej pożądliwości, przeszkodą, jeźeli chodzi o współźycie z siostrami żon, był przykład Patriarchy. A cóż nam naleźy czynić? Mówić o napisanym, czy teź wyjawić to, co zostało przemilczane? W prawach tych bowiem również nie napisano, że ojciec i syn nie powinni chodzić do jednej nałoźnicy, ale prorok poddaje taka praktykę ostrej ocenie mówiąc: "Syn i ojciec chodzą do jednej dziewki" /Am 2,7/. A ileź jeszcze innych rodzajów poźądań nieczystych wyuczono w szkole demonów, o których milczy Pismo Święte? Nie chcąc naruszać swojej powagi nazwami grzechów, Pismo oznaczyło nieczystość tylko ogólnymi nazwami, jak mówi Apostoł Pawez: "A rozpusta i wszelka nieczystość lub chciwość niech nawet nie będą wymieniane wśród was, jak przystoi świętym" /Ef 5,3/. Pod pojęciem nieczystośc1 Apostoł miał na uwadze wszelkie niegodne nazwy czyny mężcyzn i kobiet. W ten sposób przemilczenie nie daje pozwolenia zwolennikowi poźądliwości. A ja mówię, że prawodawca nie przemilczał tego rodzaju nieprawości, ale bardzo ostro zakazał. Słowa bowiem: "Nikt nie będzie się zbliżał do swojego krewnego, aby odsłaniać 
jogo nagośćl Kpł 18,6/, zaw1erają wobie i ten rodzaj pokremieństwa. Któz może być bowiem dla męża blizszym od jego zony, czyli od jego ciała? ponieważ "nie są już oni

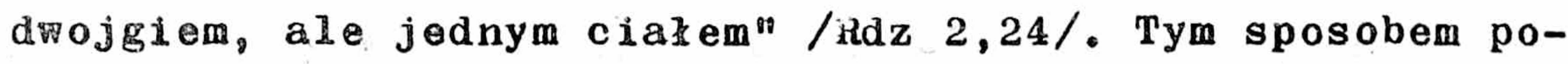
przez żone siostra jej staje się krewna męż. Dlatego nie moźna poślubić matki żony i jej slostry, poniewaź swojej matki i jej siostry teź nie można poślubić. Tak samo nie moźna poślubić siostry swojej żony, gdyż nie moźna wziąć za żone masnej siostry. Odwrotnie, nie wolno teź żonie współżýc z krewnymi męża, gdyż prawa pokrewieństwa sa ¥spólne dla obu. Ja zaś kaźdemu, kto prosi o radę w sprawach małzeńskich ośwladczam, że przemija postać tego świata 1 czas ma swój kres, "dopóki jednak trwa, winni równiez cí, którzy mają żony żyć tak, jakby ich nie mieli" $/ 1$ Lor $7,29,31 /$. A jeżeli ktoś sprzeciwi sie i przytoczy słowa "rośnijcie i mnózcie się" / kdz 1,28/, to zaśmieję się nad tym, kto nie rozróżnia czasóm dawania prawa. Powtórne małżéstwo jest lekarstwem przecíko nierziłowi, a nie zadośćczynieniem swym zachciankom. Powiedziano bowiem: "Jeśli nie moga zachować wstrzemięźl1wości, niochaj wstępuja stan małzeáski" /1 Kọ 7,9/. "N1ech wstępują w stan malzésk1", co ni@ znaczy, ż@ maja popełniać nieprawość. Ci zaś, którzy plamią duszę pożądliwościami, nie bacząc r.r naturę od dawna rozróżniajazca nazwy pokrewieństwa. Jaką nazwą określaz potomstwo zrodzone $z$ dwóch takich małżenstw? Braćmi rodzonymi czy też kuzynami? Z powodu pomieszania/pokrewieństwa/ właściwa będzie dla nich jedna i druga nazwa. Nie czyń, człowieku, ciotki swych dzieci ich macochą, a tej, stóra zamiast zmarłej matki powinna je pieścić, nie pobudzaj do niepohawowanej zazdrości. Jedynie bowiem zazdrość macoch nawet poza grób rozci zga nienawiść. Nawet wrogowie jednajiz si ̨ zmarłymi, macochy natomiast od momentu śmierci zaczynajú wzrastać w nienawiści. $Z$ tego co powiedziałem wynika, że jeżeli kimś kieruja popędy, to tym bardziej należy zabronić mu zawierania małżéstwa, "aby umiał utrzymać swe ciało w czystości i poszanowaniu, a nie w namig̨tności żądzy" /1 Tes 4,4-5/. Nie chcę już więcej mówić, gdyż powstrzymuje mnie objętośc listu. Pragnę, aby 
ta nieprawość nie zadomowila się wasmym rejonle, ale pozostała w tych miejscach, gazie miano odwage ja popelni $c^{59}$.

3. Tymoteusz Aleksandryjsk1/+385/60

Kanon 5:

Jeżeli zona współzyje ze swym mężem wocy, lub mażz ze swą żoną, a rano ma miejsce zebranie eucharystyczne, to czy moga oni przystapić do komunil?

Nie powinni. Mówi bowiem Apostol: "Nle odmawiajcie sobie wzajemnie, chyba za obopólną zgoda na pewien czas, aby oddać się modiltwie, a potem znów wróćcie do sieble, aby was szatan nie kusił z powodu waszej nlewstrzemieźlimości " $/ 1$ Kor $7,5 / 61$ 。

Kanon 11:

Jeżeli ktoś wezwie kapłana na ceremonie małżéską, a ten usłyszy, że zawierane mażeństwo jest nieprawe, lub między krewnymi, lub też że panna mioda jest siostrą zmarlej żony, to czy kapłan winien im towarzyszyć, lub tez składać za nich ofiarę?

Odpowiem jednym słowem: jeżell kapłan usłyszy, że mażeństwo jest nieprawe i jożeli to malzeristwo Paktycznie jest nieprawe, to kapłan nie powinien uczestniczyć w cudzych grzechach 62 .

Kanon 13:

W jakie dni tygodnia małżonkowie winni powstrzymywać się od współżycia, a w jakie dni mają do tego prawo?

59 Joannou II, 162-169/Ep. 160 ad Diodorum/.

60 Przepisy dotyczazce mał żeństwa zaczerpnięte są z jego "Responsa canonica" - odpowiedzi na tematy prawne i. moralistyczne, PG 33, 1295-1310, Joannou II, 240-258.

61 Joannou II, 242-243.

62 Joannou II, 246-247. 
Podtrzymuje to, co przedtem powiedziałem. Apostor mówi: "Nie odmawiajcie sobie wzajemnie, chyba za obopólnaz zgodą na pewien czas, aby oddać się modlitwie, a potem znów wróćcle do siebie, aby was szatan nie kusił z powodu waszej niewstrzemięźliwości" / 1 Kor $7,5 /$. Trzeba jednak koniecznie powstrzymywać się wobotę $i$ niedzielę, gdyż w te dni składana jest Bogu ofiara duchowa ${ }^{63}$.

Kanon 15:

Jeżeli czyjaś żona jest opętana do tego stopnia, że nosi okowy, a jej mazż mówi, że nie może się opanować, i chce poślubić inną, to czy może to uczynić, czy też nie?

Występuje tu problem cudzołóstwa i nie wiem co na to odpowiedzieć 64 .

4. Teofil Aleksandryjski / $412 /$

Kanon 5:

Sprawę Panufa, wyświęconego na diakona w Lyko, należy dokładnie zbadać. Jeźeli zostanie dowiedzione, że będąc jeszcze katechumenem pojął on za żonę swoją siostrzenicę i po chrzcie został wprowadzony do stanu duchownego, to niech w nim pozostanie, jeżeli ona umarła, a on po chrzcie z niz nie współźył. Jeżeli jednak pojał siostrzenicę za żonę będąc już wiernym, to niech zostanie wykluczony ze stanu duchownego. Nie można tu też niczego zarzucać biskupowi Apollonowl, jezeli go nyświęcit z niewiedzy ${ }^{65}$.

Kanon 6:

Sprawę Jakuìa trzeba zbadać. Jeżeli będąc lektorem okazał winnym grzechu nieczystosci 1 zostaz przez kapłanóm usunięty, a potem przyjął święcenia, to niech zostanie wykluczony [ze stanu duchownego], po dokładnym zbada-

63 Joannou II, 248-249.

64 Joannou II, 250.

65 Joannou II, 266-267. 
daniu sprawy, a nie tylko na podstawle podejrzenia pochodzącego z plotek i złośliwości. 'Jeżeli się okaźe niewinnym, niech pozostanie w stanie duchownym. Nie nalezy bowiem zważać na nieuzasadnione zarzuty ${ }^{66}$.

Kanon 13:

Maksym twierdzi, że zawarł nieprawy zwiazzek małżeński, poniewaź nie znał praw kościelnych. Smucl go jednak odłączenie od wspólnoty kościelnej twierdząc, ze popełnił nieprawość z niewiedzy; powstrzymuje siẹ przy tym od nieprawego współzycia, na co godzi się i jego zona. Jezeli sprawdzisz, źe faktycznie tak jest i minęło juź od ich ślubu dziesiéć lat, to można ich umieścić wśród katechumenów. Uczyń tak. Jeżeli jednak zauwaźysz, że chcq oszukiwać i potrzeba przeciwko nim jeszcze trochę surowości, to uczyń tak, jak ci podsuwa Bóg, kierując się we wszystkim rozwagą. Będąc na miejscu lepiej możesz poznać ich zamlary ${ }^{67}$.

tłum. ks.Henryk Paprock1 - Warszawa

66 Joannou II, 267.

67 Joannou II, 272. 